\title{
European Union's Institutional Reform Options and Their Impact to a Small Member State: The Case of Estonia
}

\author{
Viljar Veebel $^{1}$ \\ ${ }^{1}$ Estonian National Defence College, Tartu, Estonia \\ Correspondence: Viljar Veebel, Estonian National Defence College, Riia 12-402, Tartu 51013, Estonia. E-mail: \\ viljar.veebel@gmail.com
}

Received: May 19, 2014

Accepted: June 5, 2014 Online Published: August 25, 2014

doi:10.5539/jpl.v7n3p47

URL: http://dx.doi.org/10.5539/jpl.v7n3p47

\begin{abstract}
Complications with decisive decision-making and policy implementation during the European financial crisis have initiated the debate on necessity of the European institutional and legal reforms in upcoming years to avoid similar complications in the future. The list of problems to be fixed is long: the lack of transparency in terms of member states' joint obligations, insufficient scrutiny, an absence of clear norms and convincing sanctions, and the inability of the central institutions to regain control over member state violations of the Eurozone criteria are some examples of problems to be solved with planned reforms. The visions of solutions are also different, varying from the federal union, to the "stakeholders" union inspired by the IMF model, but also a simplification and reparation of the current community model is seen as one possible option. Which would be the legal, institutional and fiscal effects of planned institutional reforms and how they influence existing decision-making logic and balance from the perspective of small member states are the main research questions of this article.
\end{abstract}

Keywords: European Union, federalization, stakeholder model, institutional reform

\section{Introduction}

The hope and illusion that the European integration is a well-built mechanism, leading seamlessly to economic welfare and to political harmony, has been lost and cast away in recent years of financial crisis and institutional fights (Barroso 2012; Cameron 2013, 1). In the light of the financial crisis, the European Union's institutional system and the governance quality has been a target for critics from the public, economic actors, media and academia. Growing critics indicates that a wide gap exists between expectations of the European society, its legal competences and institutional decision-making mechanisms.

Which are the problems to overcome, which are possible reform scenarios and which should be the position of small Member States - such as Estonia - in this reform process? What is there to be gained or lost in case of different options and scenarios? How, will institutional reforms impact European Union's economic and financial problems?

The list of the challenges and necessities is long - most of them have been initiated from the Eurozone financial crisis and fiscal imbalances, but they also reflect deeper institutional problems in the EU, which were admitted already during the preparation of the Lisbon Treaty. The lack of transparency in terms of member states' fiscal obligations, insufficient scrutiny by the European Commission and the European Central Bank, an absence of clear norms and convincing sanctions causing the inability of supranational institutions to regain control over widespread member state violations of the Maastricht criteria are some examples indicating the need to reform the legal and institutional system of the European Union.

The visions and interests of the Member States in terms of a new institutional structure, legal model and power division differ also in wide range: when some Member States (The United Kingdom, Czech Republic and Denmark) prefer to renovate the existing community model of the functional integration; a second group supports federalization (Belgium and France) and a third group prefers so called 'stakeholders model' (Germany and Luxemburg). Therefore, after 60 years of the evolutionary integration process, the Member States of the EU are once again facing a dilemma - whether to continue with the existing model of integration, to develop within a reform process into a federal state or continue the reforms in manner already used to institutionalize the European Stability Mechanism (ESM). 
Instead of idealistic debate, the options concerning institutional reform should be based on measurable results, rational argumentation, legal applicability, open debate and inclusion. Idealism, optimism and solidarity may be a part of the incentives for the European cooperation, but not necessarily the best baseline for building an institutionally stable, economically competitive and fiscally sustainable Europe in a long term. In process of debate and scenario selection, there is also no need to underestimate the critics to the federal model, functional model or stakeholders model, as they help to find potential weaknesses or bottlenecks and therefore throughout the debate improve the end-result. This means also that the national competence in assessing the developments of institutional reforms must increase among civil servants, academia, media and public.

The impact and interest representation of the small Member States is eased by the fact that their objectives are in many aspects similar to the objectives of bigger Member States and to the EU institutions: more legitimacy, more effectiveness, more democracy and transparency in political processes. The central question is how to achieve these results in acceptable way for all European social stakeholders and Member States.

The main aim of the following study is to compare three main institutional reform scenarios of the European Union in terms of the applicability and impact to small Member States. The study is based on hypothesis that a reparation and simplification of existing community model is both most achievable and beneficial for small Member States.

To answer the research question and test the hypothesis, following article will first introduce and analyze all three main reform options in terms of the theoretical expectations and empirical circumstances. All three scenarios will also be analyzed in terms of applicability and effect to small Member States' representation. Fourth chapter will use the comparative approach to evaluate reform scenarios in terms their applicability and effects. The central variables influencing the attractiveness of previously described three institutional reform scenarios are the actual level of national representation and influence in the institutions, the level of sovereignty to be shared between Member States and institutions and amount of return gains in terms of security and welfare (Antola and Lehtimäki 2001, 7). The case of Estonia will be used in this analyze as example to illustrate the terms of debates, the choices and outcomes and possible differences between the most debated reform scenarios and to indicate the main dilemmas and questions.

\section{The First Option for the Institutional Reform: The Stakeholder Model}

The Stakeholder model of the institutional build-up represents the business based vision for sustainable governance to prevent a fiscal irresponsibility and possible abusing of the European solidarity to cover growing national debt of some Member States both nowadays and in upcoming years.

The central principles of the stakeholders model (see Mitchell, Agle \& Wood, 1997: 857) have already been used to design institutional system of the European Stability Mechanism (ESM) and the European Financial Stability Facility (EFSF) - the symbols of the future economic and fiscal cooperation in Europe - are economic reasoning, rationality and profitability; protection of the interests of the creditors, confidentiality, the correspondence of the Member States' representation to purchased shares and the complete voting dominance of majority over the minority according to the distribution of votes (The ESM Treaty, 2012). The corporate model that was chosen to govern the ESM and the EFSF is also used in governing the International Monetary Fund.

In contrast, the core values of today's European Union's institutional and legal system are consolidative democracy, culture of consensus, inclusion of all main interest groups, transparency of the legislation, as equal treatment of the Member States as possible, solidarity and support to weaker Member States and societies, respect of the diversity and support of the peripheral areas at the expense of the market economy principles.

The Stakeholders model is based on the institutionalization logic and values of a profit-focused business corporation, while the existing community model of the EU on the other hand is based on solidarity and overrepresentation on smaller Member States.

As a result, in 2014, the EU finds itself in a situation, where the ESM and the EFSF - institutions created to halt the financial crisis and secure financial stability in the future - share the values of neither the present European Union nor of the debated federal Europe, although they were invoked as if to save the EU today, start building a federation and legitimized on the integration mandate given by citizens in past referenda.

The necessity of such decisive change in values and rules concerning the joint EU governance have been justified by the inability of the present EU to continue with the model of solidarity and overrepresentation of small Member States, in the case of which some indebted small Member States may, deriving from the particular voting system (the qualified majority voting) of the EU, to ask for additional funds and block the counterbalancing proposals of 
'responsible Member States' to restructure the debts and to rebalance their national budgets with joint costs (Lane 2010, 59-60).

In practice the Stakeholders model in the ESM and in the EFSF works as follows: each Member State of the Eurozone is allowed to buy shares according to its Gross Domestic Production (GDP). The number of shares bought by the Member States also reflects directly on the weight of its future votes on appointing the governing bodies of the institutions, making the key decisions and re-allocate the funds. Therefore, for example, in the ESM Germany has $27 \%$, France $20 \%$, Italy $18 \%$, Finland $1.8 \%$ and Estonia $0.186 \%$ of shares and votes (in EFSF $0.255 \%$ ) what is even less than the proportion of Estonian population from the population of the EU (Estonia holds $0.3 \%$ of the EU population). No compensatory mechanism are used to make representation of small Member States more visible (The ESM Treaty, 2012).

How does this division of votes and representation differ from the Estonian current representation in European Commission, in European Court of Justice, in European Parliament and in Council of Ministers? Estonian representation (as stated in Lisbon Treaty) in European Commission and in Court of Justice are 3.57\%, in European Parliament $0.8 \%$ and in Council of Ministers $3.57 \%$ or $1.23 \%$ depending if the qualified majority voting or the consensus voting is used. Calculated average of the Estonian representation in the EU, according to the community model voting division is $2.58 \%$ what is 13.9 times higher than the representation in ESM and 10.1 times higher than representation in the EFSF.

This difference is even more visible when considering the actual voting rules of the ESM and the EFSF by the majority voting. As stated in founding treaties of the ESM and EFSF, from the beginning of 2014, among the eighteen Member States of the Eurozone Germany, France and Italy have altogether $65 \%$ of the votes and the rest fifteen Member States will control only 35\% of the votes. Decisions on additional payments, investments of funds, sharing the profit and possibly returning the paid-in capital will be taken with the same weights of votes as described before. As a result, a qualified majority of votes, needed for decision-making and levelling in $80 \%$, may be achieved with the votes of the five biggest Member States.

In parallel, to pass a legislative act in the Council of the European Union that represents the consensus tradition in the EU, it takes at least 260 votes of 352 possible, which is approximately $74 \%$ of the votes, as well as half-plus-one of the Member States (or at least 2/3 of Member States if the legal proposal is not initiated by the European Commission) and $62 \%$ of the population behind the Member States.

It is also worth noting that in order to gain a $0.186 \%$ voting share in the ESM and $0.255 \%$ voting share in the EFSF, Estonia took the responsibility of making a payment of 148 million euros and as a shareholder to take obligations for up to 3 billion euros (roughly 2500 euros per capita), which is almost $50 \%$ from the Estonia's central budget revenues in year 2013 (Bank of Estonia, 2013).

Even if the corporate 'stakeholder' model of the governance of the ESM and the EFSF is in German, French and Italian opinions' one of the best ways to solve the financial crisis and conforms better to the principles of the market economy where 'the one who pays the bill can also order the music', it may be questioned, whether a $0.186 \%$ and $0.255 \%$ voting right for a possible 3 billion euro obligation was precisely how small Member State like Estonia pictured itself sharing in the solidarity of the EU and being participating as equal nation state in the European affairs (Veebel \& Markus, 2013: 61).

Despite discouraging facts of a low representation, small Member States Estonia has also been one of the Member States in support of the stakeholder model (as a possible institutional reform scenario), stressing that the state functions may be carried out more successfully by using the corporate model of governance in the European level and in some aspects of fiscal and financial stabilization stakeholder model may have advantages because support of net payers, who are also the main subjects for the additional future payments for stabilization. The main supporter of stakeholders' model in Estonia has been Minister of Finance Mr. Jürgen Ligi, stressing (Estonian Parliament, 2011) that stakeholder model is both more effective in terms of decision making and also more ethical than existing 'community model' as it gives the right of the decision to those countries who actually pay for the policy implementation. This approach has also been openly supported by former Prime Minister of Estonia Andrus Ansip (Estonian Government, 2011).

To summarize: from the three options on table for the institutional reform, the stakeholder model offers by far smallest representation for the small Member States with the small GDP like Estonia and tends to over represent larger Eurozone countries with bigger population and bigger GDP like Germany, Italy and France. Accordingly the biggest Member States of the European Union would prefer this model before federalization or renewing existing community model. 


\section{The Second Option for the Reform: The Federal Model}

During the European sovereign debt crisis, 'federalization' has been seen as one of the possible solution to avoid future financial crises and to end Member States' growing disrespect of the Eurozone rules (Barroso, 2012; Mugge, 2011; Schmidt, 2010). On the other hand, debates on the creation of federal Europe are more than 60 years old and were started already when the European Communities were founded; were re-debated again 25 years ago, when the Maastricht Treaty was prepared, as well as at the Convention on the Future of Europe in beginning of the new Millennium when the European Constitutional Treaty was prepared, but all of them ended without any direct federal impact or 'federal trace' to official legislation procedure. None of the aforementioned Treaties state the creation of a federal union as an objective - instead the Treaties emphasise enhanced cooperation (the idea and slogan of 'ever closer union'), supranationalism and deeper integration. Most disappointing for the supporters of federalism was the case of the European Constitutional Treaty, which was initiated with Laeken declaration specially by the federal ambitions, but which did not bring any measurable federal progress when finally enforced as the Treaty of Lisbon in 2009.

Historical experience also raises a question, if federalization is at all a native or applicable part of the European integration and if the federal union would solve the main problems of the EU, why it has not yet achieved (Kregel 2011).

Therefore it may be stated that the idea and model of federalisation is not causally linked to the logic of European integration by the Treaties or even in essence. In legal terms it means, that the European citizens as electorate have not given a mandate at any referenda to the policy-makers to create a federal union and also the Member States' accession treaties to the EU have not foreseen the possibility of the union evolving to a federation.

Theoreticians of the European integration, such as Ben Rosamond (2000), Manuel Porto (2004), Joseph Weiler (1991) and Simon Hix (1999) have been sceptical towards feasibility and expediency of federalisation based on historical experience. The main hurdle for the successful federalisation so far that may also prevent it in the future is that a smooth transition from the current constellation of Member States to a full-fledged federation is inconceivable - it is not prudent, as there are several Member States that in principle oppose the federal model altogether (Veebel \& Hurt, 2013).

Which additional value would federal model of Europe offer in economic and political terms? How could successful federalization be achieved in practice with existing legal bases and traditions? Will the majority of the Member States support the federalization process? Can federal model and existing integration model be peacefully and successfully be combined? Is there any specific effect of the federalization which influences the representation and participation of small Member States?

The general aim of the European federal reform would be to gain more administrative and political control over Member States' fiscal policies, consolidate already conducted reforms in financial sector and to reach a fundamentally new qualitative level of the European Union unification process (Fischer, 2000: 1-2; Rosamond, 2000). But there is no evidence that federal reforms will help to rise EU competitiveness, bring more funds to the EU budget or increase export. Accordingly, a dominative hope among federalization supporters, that more Europeanization, cooperation and centralized scrutiny adds economic or fiscal efficiency, has not been proven scientifically (Kregel, 2011: 7).

The second central question in terms of the institutional reform is, in which way the federal Europe would differ from the current Union with its institutional logic and legal principles. In ideal model, a federal reform would bring a clear, standardized, fixed, legally binding and stable political and institutional of power between the EU institutions and the Member States with mechanisms of additional scrutiny and coercion. In practice a federal relationship ought to create situation in which problematic Member States would not be able to abuse joint resources and solidarity to solve their debt issues, by transferring the responsibility and the cost on the shoulders to other Member States. It will also be clearly stated, which competences are delegated to a federal level and which will remain in the hands of the national governments. Federalization will force the EU to achieve a stability by uniformity of all Member States despite their differences in terms economic development, their geographic location or social traditions. This will, at least in short run improve the financial health of the EU and Member States in debt, but it will be achieved with the expense of slowing down of the development of the stronger Member States. Unification of the overcapitalized gigantic Germany or miniature Luxembourg on one hand, and the deeply indebted mid-size Greece and Portugal on the other would, have to step into the same size and model of budgetary pair of trousers, which would hinder the progress of both groups. As a result the EU as a union will in future be less able to use its special economic and social differences and advantages (Alesina, 
Ardagna, Galasso, 2010; Kregel, 2011: 5).

One of the main disadvantages of the federal model of the EU is that in several aspects it confronts with the existing model of functional integration, also known as 'community model' (Rosamond, 2000). First, existing 'community model' allows membership in the EU also for the Member States which do not want to participate in all common policies (The United Kingdom, Sweden, Denmark and Ireland have their own interests in terms of common currency or Schengen Visa area). Second, existing model allows flexible combination of governance with the supranational and intergovernmental institutions (Weiler, 1991: 405). Third, if proposed model of the European Federation will bring to Member States less control over political agenda and less competence control, what would be their interest to support this process (Moravcsik, 1998: 35-38)? This concerns mainly the interests of big Member States, who's representation in the federal model would probably be lower than it is in the stakeholders' model or in the existing division of votes and seats.

But the main weakness of the federal model of Europe, when to compare it with the existing 'community model', will be its fixed nature and lack of dynamics, flexibility and progress. Possible federal treaty between Member States and central supranational institutions would mean fixing the European integration process to a certain level and locking the chosen option for all parties. For example, in case of a financial crisis it would not be operatively any more possible to redistribute competences as it was done in in 2012. Accordingly, federalization would keep the part of integration concerning delegating competences to joint institutions, but it would lock it concerning the process and its dynamics.

In other words, static federalism and dynamic integration are mutually exclusive: when one offers stable peace and stagnation, then the other one offers a gradual development with periodic crises and uncertainty. Both models cannot be followed simultaneously, while opting for the federalization, it also means choosing to stop further developments of integration. Would a stable but stagnant institutional solution guarantee the development competitiveness of Europe in global arena and enhancement of common European values? Apparently not - this choice would only be rational if Member States believe that the best years of integration are behind, that this model of cooperation has exhausted itself for the time being and that in current situation the focus should be on safeguarding previous achievements (Veebel \& Hurt, 2013: 2-3). Unfortunately, the aforementioned problematic aspects find rarely their way to the statements and articles of top-politicians. Federalisation is presented as an added value, which would preserve the strong-points of neo-functionalist model of integration (mostly its ability to evolve and its flexibility), but it would be topped-up clearer distribution of competences and scrutiny to prevent possible violations.

Which type of federation would be preferable for a peripheral small Member State of the EU, and which exceptions or advantages these states (From Estonia to Slovenia) would like to have in order to secure reasonable representation of their interests in the long-term perspective? The role, representation and possibilities of participation would be quite different for the small Member States in the case of different types of the federation. Therefore it is important to debate one's preferences and vital interests beforehand, agree upon a certain set of solutions and then firmly defend them. If in the interest of smaller Member States is an open and dynamic type of federation, then the existence of the different sentiments in the European Union should be acknowledged as well. There is also a number of Member States (Germany, Austria also France in some aspects) that would prefer more static type of the federation with more strict legal regulation that would grant a more straightforward legal relationship and more effective scrutiny (Raig, 2013: 12).

The federation vision has the most support within the political elites of the six founding members (Belgium, France, Germany, Italy, Luxembourg, the Netherlands) of the EU. Germany and Belgium stand out of the six for having broad experiences with the federal model of governance. Therefore it's only natural that the best known top-politicians, who have openly advocated for a federation - in the early years of the EC Altiero Spinelli, René Pleven and Paul-Henri Spaak, in 2000 Joschka Fischer and now Guy Verhofstadt, Daniel Cohn-Bendit and Herman Van Rompuy - all come from six founding Member States of the EU

The idea of the European federalization has many supporters also among the Estonian political elite (Ilves, 2013: 1), because it is seen as an alternative to a possible multi-speed of Europe model, in which the Baltic States would classify as a periphery with all the security concerns and the decline of the economic advantages. It is also believed, that small and peripheral states are better able to defend their interests in a federal union (Rumm, 2013: 2). Based on those arguments the EU policy of the Estonian government has been supportive of the federalization of the EU (Government of Estonia, 2011).

In Estonia federalization is seen as possible best alternative to counter-balance the big member states' dominance in terms of Council voting and their financial impact in the European Stability Mechanism. In legal terms, 
federalization demands additional mandate from the citizens at a referendum, to ensure the long-term legitimacy of the regard to the EU. A referendum would also initiate wider and more active public debate on the European institutional reform (Raig, 2013: 15).

For small states, federal model offers both possible threats and advantages, when compared to other possible reform scenarios. The threats are connected to effects of the centralization and unification, which reduce small states' abilities to use their specific economic advantages. Additionally federal legislation tends to reflect less peripheral problems of small states than the needs of big states in core Europe. The advantages are related to guaranteed levels of representation, participation and inclusion in, which at least in some institutions overweight the actual size of small Member States. Federalism sets also some limits to legal, administrative and cultural "melting" of the smallest states, as once again their special competences and representations are safeguarded.

When calculating possible federalization in European level Germany and Belgium stand out of the six founding members for having broad experiences with federal model of governance. From small states' top politicians, both José Manuel Barroso from Portugal and Hermann van Rompuy from Belgium have openly supported ongoing European federalization (Barroso, 2012: 1-3).

But there is also need to remember that next to six founding members of the EU which support the federation idea, it founds sceptical reception in the United Kingdom, Finland, Sweden, Austria, Denmark, Poland, the Czech Republic and some other Member States. When the critical attitude towards federalization has in most countries had passive form, then the politicians of the United Kingdom have been the source of active and vocal criticism, which reverberates in the speeches of the Prime Minister David Cameron and the leader of the UK Independence Party Nigel Farage. Other known critics of federalization like Timo Soini from Finland and Vaclav Klaus from Czech Republic come from the small Member States.

As long as we see those countries, somewhat sceptical to a federation, as our companions in the EU, the birth of a European Federation is delayed, since changing the founding treaties must be supported consensually by all Member States as well as the European Parliament. There is the choice, whether to go on as a loosely bound confederative union or to create a federation, but with significantly fewer members that in turn have more common interests (Zielonka, 2006: 35). Another quite feasible solution would be to start a process of sneaking federalization within the framework of current treaties, but it could lack legitimacy in the eyes of the European citizens.

\section{The Third Option for the Reform: A Reparation and Simplification of the Community Model}

Aside to more radical reform plans towards federalization or 'stakeholder model', one option for the institutional reform is also reparation and simplification of the existing community model of functional integration. Which are the disadvantages or misuse of previously successful and traditional integration model and can these be repaired?

The evolutional logic of the European Union's institutional development has been based on ideas of constant widening and deepening of its competences to new fields and Member States. The progress of institutional integration has been symbolized by increasing institutional bodies, growing budgets, numerous new standards, increasing re-distribution (6-7\% growth annually), subsidies and growing regulation of the markets. Joint activities and regulation have been seen as something that creates additional value a priori and needs no additional justification, whether it is in the form of the Common Agricultural Policy, the Eurozone or the Schengen Area (Porto, 2004).

As a logical result, in the times of problems the first solution is seen as additional regulation, institutional inclusion, standardization and evolutional growth of financing. Progress is defined and measured in the perspective of gradual increasing the scope of common objectives, competences and procedures both in the political and economic aspect. For example, when banking and bond markets were not acting according to expectations in 2013, new regulations, standards and supranational bodies were seen as logical solution for most of member states and institutions.

Similar logic applies also in defining of union wide problems, which are often blamed on national peculiarities (Greek budget deficit, Spanish unemployment or Italian productivity) and on insufficient legal standardization, which ought to be altered or eliminated by the joint measures ('The Fiscal Compact' for example) (Schmidt, 2010; 2003-204).

Solutions to reduce overregulation and centralization have been searched also during previous decades: to safeguard national needs and interests in the European level the principle of subsidiarity was upheld in 1980s, according to which the European Union institutions first needs to prove and explain, why and how additional 
legislation or initiative creates an added value compared to already existing national legislation. With the principle of proportionality, it was additionally stated, that joint legislation of European Union can only go as far as directly needed for actual policy goals.

Thirty years later in 2014, the situation is seen quite opposite, if there happens to be a Member State not willing to go along with some new integration initiatives during legislative process, its representative may receive a rather stern look, and question from presidency or Commission representative: "Doesn't your country wish to contribute growingly to the integration, progress and well-being of Europe?" Rejection of new legislation can only be accepted in case, when member state representative can provide proof of negative impact of new legislation to its own country and wider interests of union.

Described practical approach is based on the initial logic of the integration from founding years in 1950's, according to which common institutions, regulations, resources, values and objectives will lead the parties to further increased and beneficial cooperation (Haas, 1964; Mitrany, 1975). But, in the same time, when we are looking at the latest successful institutional reforms (The Lisbon Treaty or the creation of the ESM and the EFSF) and the impact of growing competences of the supranational institutions, we are also witnessing growing economic, political and social problems in the EU. How is it possible that ever increasing joint activities, growing competences, co-operation and integration have resulted in a 5-year economic recession, stagnation and an increase in political confrontations of member states? Could this lead to a conclusion that the European model of the institutional growth and supranational integration has exhausted itself?

Before the upcoming institutional reforms it is worth asking, whether it was the complex institutional system, financial subsidies, sharing of responsibilities in supranational bodies and 2000 new regulations and directives every year that built the welfare and stability in Europe. Or was it joint and simple system internal market to serve member states joint and overlapping regional interests in field of economy and security? Originally, the idea of internal market and customs union was not carried by rampantly escalating regulation and quieting the market signals, but quite the opposite: easier and unobstructed access to the markets of other Member States, which created more open competition, economic growth and security (Mugge, 2011: 187).

Joint activities, growing regulations and re-distribution have also a negative long-term impact that has not been reflected much in public debates, although there are some convincing examples. First, the unemployment rate in the Eurozone is higher than in the Member States outside the single currency area. The accumulation of the debts of the countries using the euro (Greece, Portugal, Ireland, Spain and Italy) has on the other hand taken place within the conditions of the single currency that have been lacking individual responsibility. Third, it is precisely the rules of the single currency and the Eurozone that have led to the drastic decrease in the productivity of the countries struggling now in debt, that they are facing payment difficulties and that their labor markets have not been able to adjust. A similar trend may be observed in the Common Agricultural Policy when seemingly more effective subsidies deepen the reduction in productivity and loss of competitiveness year-by-year.

What should the EU do in a situation, where its successful policies, growing legislation and rules are the cause of its long-term problems? Should it decrease or increase regulation, scrutiny and standardization?

This dilemma was a subject for debate already 10 years ago, when the Treaty establishing a Constitution for Europe (2009 ratified as Lisbon Treaty) was being forged. The answer that came up would be very appropriate even today, although very little effort has been made ever since to apply it. It was agreed that upgrading and updating of joint legislation and delegating responsibilities to the EU cannot stop, but in parallel a process of active deregulation and returning competences to Member States should take place, which would allow them to use their distinctive competitive advantages better. As a bonus, it would allow to retain and increase the individual responsibility of the Member States. In practice it would require a permanent working group consisting of representatives of the Member States that would select areas and issues that either need regulating on supranational level or that any joint regulation would bring adverse results.

In case-study of the small Member State Estonia, the governmental position concerning competences, redistribution and regulation levels has been changing during the ten years of its EU membership. In first years of membership Estonia supported stronger following subsidiarity, deregulation, and market liberalization and reduce of subsidies (Government of Estonia, 2004). Also intergovernmental model with dominance of nation state policy initiative was seen more meeting Estonian interests and values. Political line concerning regulation and competences started to change in 2008 (Government of Estonia, 2007). Growing regulation and integration was seen positive and providing social security, while market relations were seen failing our expectations and needing additional regulations. Principles of market economy and own responsibilities were seen obsolete and were replaced by ideas solidarity and growing competences of joint institutions. Governmental representatives also 
stated, that community model offers best possible representation for small state like Estonia.

To sum up, the European integration process has been by no doubt successful fulfilling the two main objectives that were pronounced with its creation - to grant peace and prosperity to its citizens. Therefore, before rushing into fundamental institutional reforms towards federalization or stakeholders' model it would be worth a while to modify the existing European Union in a way that it would conform to its original ideas that promote freedom, take advantage of its diversity and invigorate its economy. The main supporters of existing integration model are small Member State wishing to keep their overrepresentation and Member States which do not support fast additional integration. Main opponents of this model are big Member States wishing to increase their voting power and Member States wishing to deepen the integrity level of the Union.

\section{Debate: Central Variables and Arguments When Choosing the Future Scenario from a Small Member State Perspective}

The central variables influencing the attractiveness of previously described three institutional reform scenarios are the actual level of national representation and influence in institutions, the level of sovereignty to be shared and amount of return gains in terms of security and welfare.

The question, how much additional sovereignty needs to be delegated during the institutional reform, has been actively debated before the ratification of the European Constitutional Treaty and Lisbon Treaty in Estonian Parliament, but found no public attention during the debates over ESM, EFSF and European federalization. For small Member State Estonia the general position of government during the ratification of the Lisbon Treaty was, that more integration means more economic support and more security, while in terms of independence and sovereignty Estonia already shares these in maximum level with the NATO and the EU. Both, development towards federal model and deepening community model were seen in this aspect useful for as these would protect against the growing influence of bigger Member States.

The next variable 'actual representation in institutions' does not only mean the number of votes or seats - for smalls states like Baltic States and many other new Member States in Central and Eastern Europe, it is often more depending on amount of qualified administrative professionals, who can act professionally and decisively on these seats and with these votes. The importance and limits of human capital are for small states especially visible in periods of their Council Presidency, when both additional experts and leadership capabilities are needed. During the 9 years of Estonian membership in the EU, not the public, media or academia have debated or questioned that Estonian national representation in the EU institutions might be too small. But there have been debates, how to find sufficiently experienced and prepared candidates for high-ranking EU related positions in structures of national ministries, European Commission and Council of Ministers.

Throughout the previous institutional reforms and renewals of the treaties, the positive discrimination towards the small Member States has always been central principle to compensate their actual size. That has been one of the main principles of the European Union as it was created - to work together in consensus if possible, while taking into account the diversity of the EU. Also the possible dynamics concerning the democracy in the EU institutions has found little ground for debates as in the EU institutions Estonia enjoys overrepresentation and micro representation in the ESM and in the EFSF is not widely known. What has been communicated more often is the need to avoid creation of multi-speed Europe or at least to ensure that in case of its creation Estonia will receive the representation of core members. There is no certainty, however, that it will remain the same way in upcoming years as some bigger Member States feel that they are underrepresented in terms of their GDP and population.

Next variable, the question of gains, has been of the center of legitimization debates in Estonia since the beginning of Eurozone crisis in 2008, when debating additional sovereignty sharing, decreasing representation or growing joint rules. Estonian government ministers (Ligi, 2011) and President Ilves (Ilves, 2012) have during the membership years been in consensus, that the gains in terms of security and financial support are so remarkable, that in generally Estonia is not only satisfied with current vote distribution, but would be ready to accept every of previously debated three scenarios, including possible additional payments and reduced representation only to keep our membership. Among the government and president, the arguments about preferences have been slightly different. President Ilves prefers as much as federal solution if possible preferably following the American federal experience, with as strong economic and security connections (Ilves \& Raidla, 2013). But he has also agreed with existing reforms towards stakeholders model, by saying that despite new conditions Estonia receives more subsidies from the EU than pays to common budget and therefore should not compline. Former Prime Minister Andrus Ansip and Minister of Finance Jürgen Ligi see the European role in Estonian economy increasing, growingly important and in many aspects irreplaceable. Accordingly during the debates over the ESM and the EFSF, they have stressed that central aim during fiscal reforms is to keep Eurozone stability and 
joint solidarity with any cost, as these provide best possible economic conditions for Estonia in longer perspective. Their opinion is also supported by fact that European subsidies and investments reached to $22 \%$ from Estonian budget in 2013.

To summarize, both in terms of measurable quantitative aspects (votes and seats to be received in institutions and additional resources to be allocated) and qualitative aspects (level of sovereignty to be additionally delegated and actual ability to impact the political decision making), the most rational choice for small Member States is to continue with improving of existing community model instead of opting for federal model or stakeholders model.

Continuing improvement of existing community model is also most rational in terms of applicability, as both the federal model and stakeholders model need consensual support from Member States to replace the existing model, but have opponents among anti-federal Member States and small Member States, which do not wish to lose their existing overrepresentation in supranational institutions.

\section{Conclusions}

The European Union's battles with the financial crisis and the subsequent reforms in years 2011-2013 have been following a rather unexpected logic. First, there has been an ongoing heated debate on the possible federal future of Europe with much discussion on ideals and common values, but which has led to no practical results. Secondly, improving the present community model of integration has been quite decisively rejected both in economic and political sense, while the politicians, who have requested such debate (for example David Cameron with "Speech on The Future of Europe, 2013) have been seen as opponents of progressive integration group. Third, by using the stakeholders' model, new financially powerful institutions, the European Stability Mechanism and the European Financial Stability Facility have been created. Wider democratic participation of the public was found unnecessary even when created financial funds are several times larger than the EU budget and are governed in a substantially different manner from the legitimate logic of the EU.

The economic and financial crisis has revealed that in a club of 28 Member States it is more difficult to come to any agreement that can satisfy all the parties. The EU has been a target of criticism for both taking too long to respond adequately for recent economic setbacks as well as for trying to bypass the conventional time-consuming decision-making procedures.

Small Member States have in these developments their own possible advantages, losses and preferences. Based on previous historical experience of institutional reforms, will be intricate and face many challenges. If we wish that this effort will end with new Treaty and be also in interest of small states, then more active and targeted participation impact analysis is needed. From the position of the small member states it is central to map our objectives with regard to the European Union institutional reform and then by the proactive actions to steer the reform process instead of adjusting our behavior to the positions of the other Member States by reacting to ongoing processes and passed opportunities.

Institutional reform can and will also consist a number of risks that need to be taken into account - setbacks to reforms may bring about a greater crisis of confidence between supranational institutions, the member states and their citizens and ultimately result in the loss of credibility of the EU on international arena.

Current research indicated, that while institutional alternatives are debated and even partially tested the existing community model seems most rational both in terms of applicability and from the perspective of small Member States. As a logical result, new reform treaty is not to be expected in upcoming years.

\section{References}

Antola, E., \& Lehtimäki, M. (2001). Small States in the EU, Working Papers Jean Monnet Centre University of Turku, no 10.

Bank of Estonia. (2013). Estonia's Economy in 2013. Retrieved from http://statistika.eestipank.ee/?lng=en\#listMenu/1017/treeMenu/MAJANDUSKOOND

Barroso, J. M. (2012). Address Plenary Session of the European Parliament. Strasbourg. Retrieved September 12, 2012, from http://europa.eu/rapid/press-release_SPEECH-12-596_en.htm

Cameron, D. (2013). European Speech. Guardian. Retrieved from http://www.guardian.co.uk/politics/2013/jan/23/david-cameron-eu-speech-referendum

Estonian Parliament. (2011). Session Stenogramm. Retrieved from http://www.riigikogu.ee/?op=steno\& stcommand $=$ stenogramm\&date $=1317107100 \&$ pkpkaupa $=1$ \&paevakord $=8895$ 
Fischer, J. (2000). From Confederation to Federation: Thoughts on Finality of European Integration. Speech given at Humboldt University, Berlin.

Government of Estonia. (2004). Estonian EU Policy 2004-2006.

Government of Estonia. (2007). Estonian EU Policy 2007-2011.

Government of Estonia. (2011). Estonian EU Policy 2011-2015.

Haas, E. B. (1964). Beyond the Nation-State. Stanford: Stanford University Press.

Hix, S. (1999). The Political System of the European Union. Basingstoke: Macmillan.

Ilves, T. H. (2013). 'Ma ei saa aru tondist, mida maalitakse föderalismi ees' Postimees.

Ilves, T. H., \& Raidla, J. (2013). On European federalization. Retrieved from http://www.eurokratt.ee/ilves-ja-raidla-euroopa-foderatsioonist/

Kregel, J. (2011). Debtors'Crisis or Creditors' crisis? Who Pays for the European Sovereign and Subprime Mortgage Losses? Public Policy Brief no 121. Levy Economics Institute of Bard College.

Lane, P. R. (2010). Rethinking National Fiscal Policies in Europe. In R. Baldwin, D. Gros, \& L. Laeven (Eds.), Completing the Eurozone Rescue: What More Needs to Be Done? (pp. 59-63.). London: Centre for Economic Policy Research.

Mitchell, R. K., Agle, B. R., \& Wood, D. J. (1997). Toward a Theory of Stakeholder Identification and Salience: Defining the Principle of Who and What really Counts. Academy of Management Review, 22(4), 853-888.

Mitrany, D. (1975). The Functional Theory of Politics. New York: St. Martin's Press.

Moravcsik, A. (1998). The Choice for Europe: Social Purpose and State Power from Messina to Maastricht. Ithaca, New York: Cornell University Press.

Mugge, D. (2011). From Pragmatism to Dogmatism: European Union Governance, Policy Paradigms and $\begin{array}{llll}\text { Financial Meltown. New Political Economy, 16(2), } & \text { 185-206. }\end{array}$ http://dx.doi.org/10.1080/13563461003789753

Porto, M. (2004). Theory of Integration and EU Policies. Institute of European Studies Macau.

Raig, I. (2013). From European Federation and its Alternatives, Proceedings of Estonian Parliament.

Rosamond, B, (2000). Theories of European integration. Basingstoke: Palgrave.

Rumm, H. (2013). Võib-olla tõesti rahvusriikide föderatsioon? Postimees.

Schmidt, V. A. (2010). The European Union's Eurozone Crisis and What (not) to Do about It. Brown Journal of World Affairs, XVII(1), 199-214.

The Treaty Establishing the European Stability Mechanism. (2012). Retrieved from http://www.european-council.europa.eu/media/582311/05-tesm2.en12.pdf

Veebel, V., \& Hurt, U. (2013). Can European Integration Take Place Simultaneously with the Federalisation? Proceedings of Estonian Parliament.

Veebel, V., \& Markus, R. (2013). Why and how supranational institutions became central stakeholders in the Eurozone debt crisis 2008-2012? Baltic Journal of Political Science.

Weiler, J. H. H. (1991). The Transformation of Europe. The Yale Law Journal, 100(8), 403-483. http://dx.doi.org/10.2307/796898

Zielonka, J. (2006). Europe as Empire: The Nature of the Enlarged European Union. Oxford University Press. http://dx.doi.org/10.1093/0199292213.001.0001

\section{Copyrights}

Copyright for this article is retained by the author(s), with first publication rights granted to the journal.

This is an open-access article distributed under the terms and conditions of the Creative Commons Attribution license (http://creativecommons.org/licenses/by/3.0/). 